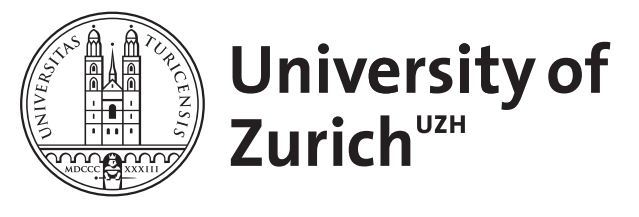

\title{
Investment competence and advice seeking
}

\author{
Bachmann, Kremena ; Hens, Thorsten
}

\begin{abstract}
This study evaluates individuals' abilities to avoid investment mistakes driven by behavioral biases and analyzes the relationship between investment competence and the propensity to seek or rely on professional advice. We use novel survey data collected from a representative sample of Swiss households. We find that - even after controlling for socio-economic and demographic characteristics - investment competence is positively related to demand for financial advice. It appears that investors who are at the highest risk of making investment mistakes are those who are the least likely to seek help from professional advisors. Therefore, supply-side solutions imposed by regulators to protect financial customers may not benefit those who need them most.
\end{abstract}

DOI: https://doi.org/10.1016/j.jbef.2015.03.001

Posted at the Zurich Open Repository and Archive, University of Zurich

ZORA URL: https://doi.org/10.5167/uzh-119586

Journal Article

Accepted Version

Originally published at:

Bachmann, Kremena; Hens, Thorsten (2015). Investment competence and advice seeking. Journal of Behavioral and Experimental Finance, 6:27-41.

DOI: https://doi.org/10.1016/j.jbef.2015.03.001 


\title{
Investment Competence and Advice Seeking
}

\author{
Kremena Bachmann ${ }^{*}$ and Thorsten Hens ${ }^{\dagger}$
}

\begin{abstract}
This study evaluates individuals' abilities to avoid investment mistakes driven by behavioral biases and analyzes the relationship between investment competence and the propensity to seek or rely on professional advice. We use novel survey data collected from a representative sample of Swiss households. We find that - even after controlling for socio-economic and demographic characteristics - investment competence is positively related to demand for financial advice. It appears that investors who are at the highest risk of making investment mistakes are those who are the least likely to seek help from professional advisors. Therefore, supply-side solutions imposed by regulators to protect financial customers may not benefit those who need them most.
\end{abstract}

Keywords: financial literacy, behavioral biases, demand for financial advice, household finance

JEL classification: D14, D83, G11, G23

\footnotetext{
${ }^{*}$ University of Zurich, Department of Banking and Finance, Plattenstrasse 32, CH-8032 Zurich, +41 44 6344822, kremena.bachmann@bf.uzh.ch (corresponding author).

${ }^{\dagger}$ University of Zurich, Department of Banking and Finance, Plattenstrasse 32, CH-8032 Zurich, and Norwegian School of Economics and Business Administration, Helleveien 30, N-5045 Bergen, +41 44 6343706, thorsten.hens@bf.uzh.ch.
} 


\section{Introduction}

A compelling body of research documents that households make serious investment mistakes. Among various pieces of evidence are findings that households hold under-diversified portfolios (Blume \& Friend, 1975; Goetzmann \& Kumar, 2008; Kelly, 1995) and exhibit a strong preference for local and home country stocks (Calvet et al., 2007; Huberman, 2001). In addition, households trade too much (Barber and Odean 2000), sell winners too early and hold losers too long (Odean, 1998; Shefrin \& Statman, 1985), and they tend to buy a stock simply because it catches their attention (Barber \& Odean, 2008). As a result, the average retail investor tends to underperform the market (Barber et al., 2009).

By and large there is evidence that individuals who are likely to make investment mistakes can avoid poor financial outcomes if they receive help from qualified financial advisors or delegate decisions to them ${ }^{1}$. In fact, the regulation of financial advisors relies, to a large extent, on the assumption that advisors are mainly consulted by unsophisticated investors in need of help. However, protective regulatory measures can be effective only if unsophisticated investors seek the support of professional advisors. Otherwise, regulatory measures will not benefit those who need them most.

In this paper, we assess individuals' abilities to avoid investment mistakes, and we analyze the relationship between investment competence and the propensity to seek or rely on professional advice. To assess individuals' investment competence, we conducted an online survey with questions that address biases in the selection and processing of information. These biases may lead to investment errors, as documented in the empirical literature on behavioral and household finance. We find that - even after controlling for socio-economic and demographic characteristics - the demand for financial advice is positively related to investment competence. Investors who are less able to avoid investment mistakes are significantly more likely to make investment decisions autonomously, whereas investors with higher investment competence are significantly more likely to delegate decisions to advisors.

\footnotetext{
${ }^{1}$ The question of whether expert financial advice truly benefits retail investors is still under debate, but there is a consensus that financial advice may improve retail investors' portfolio decisions when conflicts of interest are minimized (Bhattacharya et al., 2012). There is evidence that professionally-managed portfolios are more diversified (Gerhardt \& Hackethal, 2009) and exhibit weaker disposition effects than portfolios of retail investors (Shapira \& Venezia, 2001). Collins (2010) suggests that financial counseling can help individuals develop better financial practices.
} 
Hence, supply-side solutions imposed by regulators to protect financial customers may not benefit those who need them most. Additionally, our results suggest that educational initiatives, in particular for self-directed individuals, may be beneficial but that such initiatives should provide training in the avoidance of behavioral traps in addition to teaching basic financial knowledge.

To date, the question of whether financial advice is a sufficient remedy for inferior decisionmaking has received varied answers. One strand of the literature documents a negative relationship between financial literacy and advice seeking. For example, Hackethal et al. (2012) study the behavior of German retail investors and conclude that customers with less interest in and knowledge of financial matters are more likely than others to rely on advice. In a portfolio-choice experiment, Hung \& Yoong (2010) find that individuals with low financial literacy (both self-assessed and measured) choose to take advice more often than others. Frederick (2005) shows that individuals with lower levels of cognitive skills are more riskaverse, and both Bluethgen et al. (2008) and Gerhardt \& Hackethal (2009) find that greater risk aversion increases the demand for financial advice. Kramer (2012) finds that banking clients who view themselves as less financially literate than others are more likely to ask for expert financial assistance. Additionally, Hackethal et al. (2012) find that less sophisticated customers are less aware of the problem of conflicts of interest among financial advisors and therefore are more inclined to consult and follow the advice of advisors.

Other studies, however, suggest the opposite relationship between investment competence and demand for financial advice, arguing that more sophisticated individuals are more likely to seek advice. Lusardi \& Mitchell (2006) find that people with higher scores on financial literacy questions are more likely than less sophisticated investors to rely on financial experts when planning their retirement. Using past portfolio performance as a proxy for financial sophistication, Bluethgen et al. (2008) find that wealthier, more sophisticated and more experienced clients are more likely to seek advice. Hackethal et al. (2012) confirm the effect of investment experience and wealth on the propensity to seek advice and suggest that the effect could also be related to the higher opportunity costs of time of wealthier, more experienced investors.

While most previous studies have mainly focused on the deficiency of financial knowledge as a source of adverse decisions ${ }^{2}$, we hypothesize that financial knowledge alone may not be sufficient to avoid investment mistakes. Emotions and cognitive errors in the selection and

\footnotetext{
${ }^{2}$ Kramer (2012), in addition, considers cognitive ability but fails to find a significant effect on advice seeking.
} 
processing of information can prevent individuals from successfully applying knowledge that is available. To estimate the impact of these factors, we have designed multiple-choice questions addressing some common heuristics that investors may apply when making investment decisions. We call the ability to avoid using these heuristics investment competence. Hence, our measure of investment competence is complementary to other measures used to evaluate general financial knowledge (Brown \& Graf, 2013; Calcagno \& Monticone, 2014; Kramer, 2012; Lusardi \& Mitchell, 2006; van Rooij et al., 2007). In contrast to studies that infer investment competence from observed trading behavior, our measure of investment competence aims to capture reasoning driving suboptimal trading decisions that is not directly observable in trading data. Additionally, we target retail investors, as they are usually less experienced and face stronger financial restrictions when they decide to invest on the financial markets than banking clients or customers of brokerage firms. Hence, the questions of whether retail investors require an advisor and are willing to demand advisory services are of particular importance for them.

The remainder of the paper is organized as follows. In Section 2, we describe the data, provide descriptive statistics, explain how we assess investment competence and describe our control variables. Section 3 presents and elaborates on our results and discusses endogeneity issues. The results of robustness tests are discussed in Section 4. Section 5 summarizes our findings and concludes the paper.

\section{Data Description}

\subsection{The Sample}

Our dataset was generated by an online survey with 1,016 individuals from the German-, Italian-, and French-speaking regions of Switzerland. The participants in our survey were recruited from a pool of individuals provided by a professional market research agency in Switzerland that has experience conducting surveys on financial topics. In exchange for their participation, individuals answering most of the questions participated in a raffle in which an iPad was awarded to the winner. ${ }^{3}$ The questions were originally written in German. We used

\footnotetext{
${ }^{3}$ Compensation type did not significantly impact respondents' answers. In a separate study, we found that a fixed payment (CHF 10) did not motivate students to answer the questions differently than a chance of winning an iPad, with a market price of approximately CHF 800, raffled off among 100 respondents.
} 
professional interpreters employed by the market research agency to translate the questions into French and Italian.

The sample is representative of the underlying population with respect to age, gender and geographic location. As Table 1 shows, the respondents were 48 years old on average. Fiftyfour percent of the respondents were male, $30 \%$ had degrees from schools of applied sciences ("Hochschule"), and 18\% had university degrees. Overall, $44 \%$ of the respondents stated that their annual disposable income was between CHF 50,000 and CHF 100,000 (USD 48,500 and USD 97,000 as of December 2010$)^{4}$. Notably, 38\% estimated the value of their wealth (including savings and financial investments) to be above CHF 100,000.

\subsection{Assessing Investment Competence}

Generally, investment mistakes can result from a lack of specific knowledge and an inability to apply such knowledge effectively. In some cases, financial knowledge is sufficient to prevent suboptimal investment behavior. ${ }^{5}$ However, knowledge level does not guarantee optimal investment behavior. Emotions and cognitive errors in the selection and processing of information can prevent the successful application of knowledge, as suggested by the vast body of research on behavioral biases.

In this study, we use multiple-choice questions that aim to evaluate individual's ability to avoid biases such as the availability bias (Tversky \& Kahneman, 1973), the representativeness bias (Kahneman et al., 1974), probability matching (Vulkan, 2000), and probability weighting (Kahneman \& Tversky, 1979) as well as their ability to avoid investment mistakes such as under-diversification (Polkovnichenko, 2005) and the disposition effect (Shefrin \& Statman, 1985). An English version of the question is given in Appendix B. We refer to the ability to avoid investment mistakes as investment competence.

Table 2 shows how participants answered our investment competence questions, the percentage of participants who answered the questions in a biased way and the distribution of the biased answers. "Don’t know" answers are treated as unbiased. ${ }^{6}$ The respondents made

\footnotetext{
${ }^{4}$ The average annual disposable income per household in 2010 was 81,900 Swiss francs (USD 78,600 as of Dec. 2010). Source: http://www.bfs.admin.ch/bfs/portal/de/index/themen/20/02/blank/key/einkommen0/niveau.html

${ }^{5}$ For example, Dhar \& Zhu (2006) find that individuals with higher financial literacy are more likely to avoid suboptimal portfolio decisions, such as those associated with the disposition effect.

${ }^{6}$ The results remain qualitatively the same if we treat "Don't know" answers as missing. Although the number of observations decreases, the impact of the investment competence index remains significant (see Table C.4 in the appendix).
} 
the most errors in recalling and comparing the past returns of asset classes, deciding how many assets are needed for portfolio diversification and assessing the attractiveness of assets with large but unlikely payoffs. Participants made the fewest mistakes in deciding whether to take risks after losses, estimating the probability of losses from long-term investments and comparing the importance of different performance drivers. Overall, $50 \%$ of the participants answered between four and five questions incorrectly, 0.4\% (4 individuals) made no mistakes, and $0.9 \%$ ( 8 individuals) answered 9 of 11 questions incorrectly, providing the highest number of incorrect answers in the group. Notably, 9\% failed to answer at least one question. To obtain an overall measure of the individual's ability to avoid investment mistakes, one could compute the number of biased answers. However, the disadvantage of this approach is that each question receives the same weight, even though the degree of discrepancy between the biased and unbiased answers differs from question to question (see Table 2). Essentially, the questions may differ in their difficulty levels, as they address different investment mistakes. The latter can be driven by financial knowledge but also by emotional or cognitive factors. ${ }^{7}$ For this reason, we use a relative measure based on a weighting scheme that considers this issue. ${ }^{8} 9$ The weights apply a higher penalty to mistakes in answering questions where a larger proportion of the participants answered correctly ("easy questions") and a lower penalty to mistakes in answering "difficult" questions. For example, the question "performance drivers" can be considered as an "easy question," as $76 \%$ of the respondents answered it correctly. Hence, mistakes in answering this question receive a weight of 0.76 , which is relatively high.

\subsection{Demand for Financial Advice}

Financial advisors can be endowed with decision-making authority or play a purely advisory role. Swiss banks offer both options only to wealthy individuals, but some independent advisors offer advisory services to less wealthy individuals as well. We asked respondents to

\footnotetext{
${ }^{7}$ In fact, the correlations between the bivariate variables indicating investment mistakes are relatively low (except for the last two questions, which both address the disposition effect). This observation suggests that our investment mistakes questions do not necessarily have a common driver.

${ }^{8}$ The weighting scheme is the first step of the PRIDIT scoring method devised by Brockett et al. (2002), who use it to assess insurance fraud based on several indicator variables. In the second step, a principle component analysis is used to analyze the rescaled responses. Lusardi et al. (2012) use this method to assess financial literacy among the elderly in the U.S. We do not employ the second step because the responses to our investment competence questions show little correlation.

${ }^{9}$ Our qualitative results hold with alternative specifications, as discussed in Section 4.
} 
consider their present or a potential financial advisor (at a bank or otherwise) whom they view as reliable and then choose the option that best describes their current attitude toward acquiring and relying on the advice. The distribution of answers is summarized in Table 3.

Twenty-two percent of all respondents state that they prefer to make investment decisions autonomously, $60 \%$ would consult one or several advisors before making decisions, and 15\% would rely largely or completely on an advisor. Calcagno \& Monticone (2014) asked a similar question of banking clients in Italy in 2007. Of the clients who participated in the survey, $12 \%$ indicated that they make their decisions autonomously. The higher percentage of self-directed individuals in our sample (22\%) could be a function of the participants' ages. Some studies provide evidence that younger individuals are more likely to make investment decisions autonomously (Bhattacharya et al., 2012; Bluethgen et al., 2008; Hackethal et al., 2012; Kelly, 1995). In our sample, $56 \%$ of the participants are less than 50 years old, whereas the percentage of banking clients under 50 in the sample of Calcagno \& Monticone (2014) is $38 \%$. The results that we report below support this finding.

To avoid estimation difficulties that can result from the use of too few observations in a given category, we pool participants who are willing to delegate all decisions with those who are willing to delegate most decisions. As a result, we obtain a dependent variable with four categories.

\subsection{Control Variables}

Similar to other studies on advice seeking we include age, gender, household's income, household's wealth, real estate ownership, investment experience, self-employment status and education as controls in our regressions. As additional control variables, we assess individuals' degree of reliance on various information sources, specifically, the perceived importance of price movements, media news, friends' recommendations, own judgments, and the opinions of one's own advisor and of several advisors. For the average participant in our sample, the most important source of information is one's own opinions, followed by price movements and the opinions of one's advisor (see Table 4). Moreover, individuals appear to simultaneously rely on more than one information source (see Panel B). A principal component analysis indicates that reliance on information sources can be captured by three components. The first includes reliance on price movements, media news and one's own opinion; the second captures reliance on one or several advisors; the third is based on reliance on friends' recommendations (see Table C.3 in the appendix). 
Our proxy for investment experience is based on self-reports (see Table C.1 in the appendix). The average respondent in our sample has only limited investment experience, and $22 \%$ of respondents state that they do not have any investment experience at all. In contrast, only $1 \%$ of respondents state that they have extensive experience in all asset classes. We use principle competent analysis to build an index of investment experience (see Table C.2 in the appendix).

Table 5 shows the average values of our control variables for each group of respondents, indicating different propensities to seek advice. In particular, we see that advice seeking increases with the level of investment competence. The statistical significance of this observation after controlling for various demographic and socio-economic variables is tested in the next section.

\section{Results}

We present our empirical findings in this section. First, we show our results regarding the relationship between investment competence and advice seeking. Then we analyze the direction of causation and perform various robustness checks.

\subsection{Investment Competence and Advice Seeking}

In this section, we analyze the relationship between individuals' investment competences and their propensities to make investment decisions autonomously, to consult one or several advisors and to delegate decisions. While the relationship between investment competence and some of the control variables (in particular, gender, income, and real estate ownership) is statistically significant (see Table C.6 in the appendix), the corresponding interaction terms do not significantly affect delegation decisions (see Table C.5 in the appendix). In the analysis that follows, we consider only the main effect of investment competence on the delegation decision. Table 6 reports the marginal effects of partially proportional odds estimates on the probability of choosing one of the four delegation options. The results show that investment competence positively influences the demand for financial advice. When investment competence increases, the probability of delegating decisions increases; when investment competence decreases, the probability of deciding autonomously increases. Individuals with lower investment competence are also more inclined to consult one than several advisors before deciding, and this attitude cannot be fully explained by socioeconomic variables such as income and financial wealth. 
Other interesting observations emerge from comparing the effects of different information sources. Confident individuals rely on information inferred from media and previous price movements (see correlations in Table 4), and the stronger their confidence in their own judgment, the more likely they are to decide autonomously and not delegate decisions to advisors. As expected, the perceived value of an advisor's recommendation increases the probability of consulting an advisor and of delegating decisions and decreases the probability of deciding autonomously. Interestingly, individuals who rely on the recommendations of friends are more likely to consult several advisors and less likely to delegate decisions. It appears that friends' recommendations support individuals' confidence in their own investment competence, so that individuals prefer not to delegate decisions. However, friends' recommendations are taken with greater caution than media news and price movements.

The impact of self-assessed investment experience on demand for financial advice is also worth noting. Similarly to the perceived importance of media news, price movements and own judgment, a stronger sense of experience increases the probability of deciding autonomously and decreases the probability of delegating decisions. Additionally, individuals who feel more experienced are less likely to consult several advisors and more likely to rely on the opinion of one advisor when making decisions. Stated investment experience appears to reflect perceived investment competence. However, we find that the relationship between perceived and assessed investment competence is not significant (see Table C.6 in the appendix). If perceived and assessed investment competence are not correlated, then selfdirected investors appear to be trapped. Those who remain longer in the market demand less financial advice but at the same time do not exhibit a stronger ability to avoid investment mistakes than others, i.e., the probability of surviving without advice is theoretically lower than previously anticipated by decision-makers.

Finally, we find that some of the variables that capture the opportunity costs of time define an additional driver of demand for financial advice. In our sample, individuals with relatively little wealth $(<100,000 \mathrm{CHF})$ are less likely than wealthy clients $(>300,000 \mathrm{CHF})$ to delegate decisions or consult several advisors and are more likely to decide autonomously. This is in line with previous studies that find that the demand for advisory services increases with wealth (Bhattacharya et al., 2012; Bluethgen et al., 2008; Calcagno \& Monticone, 2014; Guiso \& Jappelli, 2006). We also find that the demand for financial advice increases with age, which is consistent with previous findings (Bhattacharya et al., 2012; Bluethgen et al., 2008; 
Hackethal et al., 2012; Kelly, 1995). Gender, higher education, self-employment status, household size, real estate ownership and income appear to be unrelated to decisions to seek financial advice or to delegate financial decisions.

In summary, self-directed individuals are more likely to be younger, less wealthy, feel more experienced, have lower levels of investment competence, and rely more on their own judgment, on price movements and on media news and less on the opinions of advisors than other individuals. Individuals who consult advisors before making investment decisions have the same profile as self-directed individuals but rely more heavily on advisors' opinions and pay less attention to price movements, media news and their own judgment. Individuals who delegate decisions are more likely to have higher investment competence and to rely less heavily on media news, price movements and their own judgment and more heavily on the opinions of advisors. They are also older, wealthier and feel less experienced in investment matters than others. Individuals who consult several advisors before making investment decisions have a profile similar to that of individuals who delegate decisions but rely more strongly on the recommendations of friends.

\subsection{Discussion}

Why do some individuals with low investment competence make investment decisions autonomously? One reason may be a lack of self-awareness. As Kruger \& Dunning (1999) suggest, less competent individuals are likely to lack the ability to recognize the limits of their competence. To test this hypothesis, we assume that awareness in the limits of the own competence is reflected in the perceived importance of the own judgment in investment questions. If individuals are aware of the limits of their competence, we should observe a positive relationship between investment competence and the reliance on the own judgment. The results reported in Table C.6 in the appendix suggest that the degree of reliance on their own judgment is in general not significantly correlated with investment competence.

An alternative explanation for the positive relationship between investment competence and advice seeking is relates to regret aversion. For a regret-averse decision-maker, consulting an advisor or delegating decisions is risky because the advisor could reveal mistakes in the individual's previous decisions. Such regret tends to be stronger for individuals who are more involved in the decision-making process (Kahneman \& Tversky, 1982). If we proxy involvement in the decision-making process by the perceived importance of one's own judgment as a source of information, we may conclude that self-directed individuals are most likely to feel regret because they rely most heavily on their own judgments (see Table 6). The 
same arguments explain why advice seeking increases with investment competence. Individuals with higher levels of investment competence may also lack awareness of their abilities but may be less prone to regret in delegating decisions because they are less involved in their investment decisions than are self-directed individuals.

It is also possible that more competent individuals anticipate advisors' incentives to reveal superior information only to the most knowledgeable clients, as suggested by Collins (2010), Calcagno \& Monticone (2014) and Bucher-Koenen \& Koenen (2011). This is possible because better-informed investors are more likely to identify the correct decision by using their own information, so that the advisor is better off providing them truthful recommendations. Poorly informed investors may choose the action preferred by the advisor even if the latter does not provide them with superior information and this may offsets the reputational cost of providing uninformative advice. More competent individuals may also consume more advisory services because of their lower marginal costs of information processing (Bluethgen et al., 2008).

\subsection{Endogeneity Issues}

The fact that individuals with higher investment competence are more likely to consult with advisors and delegate decisions does not necessarily indicate the direction of causation within this relationship. Individuals with higher levels of investment competence may consult advisors to learn from them rather than rely on their recommendations. To shed light on this issue, we employ an instrumental variable analysis, where the dependent variable is the level of investment competence, and the independent variables include an indicator variable for preference for consulting one or several advisors or delegating decisions (instrumented variable). The exogenous variables remain the same as in previous analysis (reliance on price movements, media news, own judgment and friends as information sources, investment experience, and demographic and socio-economic characteristics). We use the score from the principle component analysis summarizing the perceived importance of advisor(s) opinion as an instrument. The results of the instrumental variable analysis are reported in Table 7. In the upper part of the table, we include the estimation results of a logistic regression with the indicator variable for consulting advisor(s) or delegation as dependent variable and all exogenous variables and the instrument as independent variables. The results show that the stated importance of advisor(s) opinion significantly influences the decision to consult advisor(s) or delegate decisions. In the second stage, we use the predicted probabilities from the first stage as instruments for consulting advisor(s) or delegating decisions and estimate the 
impact of the instrumented variable on the investment competence. We observe that individuals who consult advisor(s) or delegate decisions have a higher but statistically insignificant level of investment competence. We conclude that the previously observed positive relationship between investment competence and delegation is most likely not related to learning from an advisor(s).

\section{Robustness Tests}

As discussed in Section 2.2, our index of investment competence is constructed using the weighted sums of investment mistakes. A higher (lower) penalty is assigned to an incorrect answer when a larger proportion of respondents answer the question correctly (incorrectly). As a robustness check, we estimate the relationship between investment competence and the propensity to seek and rely on advice under alternative specifications of the investment competence index. The first index of investment competence uses the sums of the respondents' investment mistakes. The next index introduces weights for the last two questions to account for their relatively high correlation. Table 8 reports these estimation results, which show that the effect of investment incompetence remains qualitatively unchanged.

One might argue that, for individuals with low investment competence, autonomous investment decisions are not costly because such individuals do not participate in the financial markets, and thus, their investment mistakes appear only "on paper." To test this conjecture, we use stated investment experience as a proxy for participation in the financial markets and re-estimate the impact of investment competence on advice seeking by excluding all individuals without investment experience.

Table 9 reports the marginal effects of investment competence on the probability of choosing one of the delegation options within this particular subsample. Clearly, the effects of investment competence and of the control variables on the probability of delegating decisions are qualitatively the same as in the full sample. We conclude that, if individuals do not learn from their experience, the "paper mistakes" they make when answering our questions are likely to materialize unless the investors delegate their decisions.

\section{Conclusion}

In this paper, we assess the ability of retail investors to avoid investment mistakes and the likelihood that investors will seek help from professional advisors. We find that individuals 
with lower investment competence are more likely to make decisions autonomously. This result holds even after controlling for various factors such as reliance on particular information sources, and socio-economic and demographic characteristics. In particular, we find that younger individuals with lower investment competence, who feel more experienced and who rely more strongly on price movements, media news and own judgment are more likely than others to make investment decisions autonomously. This result is robust to alternative specifications of investment competence and is unlikely to be driven by investors with no investment experience. Additionally, we find that it is unlikely that individuals who consult one or several advisors or delegate decisions have higher investment competence because they learn from their advisors.

Our results indicate that the individuals most in need of financial advice are those who are least likely to seek it out and rely on it. Hence, supply-side solutions aiming to protect customers may not reach those who need them most. On the other hand, letting self-directed individuals learn "by doing" may not be effective, as some mistakes are not easy to identify (Koestner et al., 2012). Learning by doing in this context is also irrational, as people tend to overweight their own experience relative to broader patterns of evidence. Hence, if the aim is to improve the investment competence of individuals, there is scope for educational initiatives on the demand-side that address the impact of heuristics on investment performance. Additional research should be undertaken to develop a better understanding of the conditions under which people learn to avoid heuristics, determine the limits of their investment competence and thus seek professional help. 


\section{Acknowledgements}

We would like to thank the participants at the $6^{\text {th }}$ annual conference of the International Finance and Banking Society (Lisbon, 2014) and University of Zurich Finance Seminar participants for their valuable comments and suggestions. We also wish to thank the Baloise group for financing the survey. 


\section{References}

Barber, B. M., Y. T. Lee, Y. J. Liu, \& T. Odean. (2009). Just How Much Do Individual Investors Lose by Trading? Review of Financial Studies, 22, 609-632.

Barber, B. M., \& T. Odean. (2000). Trading is Hazardous to Your Wealth: The Common Stock Investment Performance of Individual Investors. The Journal of Finance, 55(2), 773-806.

Barber, B. M., \& T. Odean. (2008). All That Glitters: The Effect of Attention and News on the Buying Behavior of Individual and Institutional Investors. Review of Financial Studies, 21, 785-818.

Bhattacharya, U., A. Hackethal, S. Kaesler, B. Loos, \& S. Meyer. (2012). Is Unbiased Financial Advice to Retail Investors Sufficient? Answers from a Large Field Study. Review of Financial Studies, 25(4), 975-1032.

Bluethgen, R., A. Gintschel, A. Hackethal, \& A. Mueller. (2008). Financial Advice and Individuals Investors' Portfolios. SSRN working paper 968197.

Blume, M., \& I. Friend. (1975). The Allocation of Wealth to Risky Assets - The Asset Structure of Individual Portfolios and Some Implications for Utility Functions. Journal of Finance, 30, 585-603.

Brockett, P. L., R. A. Derrig, L. L. Golden, A. Levine, \& M. Alpert. (2002). Fraud Classification Using Principal Component Analysis of RIDITs. Journal of Risk and Insurance, 69(3), 341-371.

Brown, M., \& R. Graf. (2013). Financial Literacy and Retirement Planning in Switzerland Financial Literacy and Retirement Planning in Switzerland, Numeracy 6(2), 619-635.

Bucher-Koenen, T., \& J. Koenen. (2011). Do Smarter Consumers Get Better Advice. Working paper University of Bonn.

Calcagno, R., \& C. Monticone. (2014). Financial Literacy and the Demand for Financial Advice. Journal of Banking and Finance.

Calvet, L. E., J. Y. Campbell, \& P. Sodini. (2007). Down or Out: Assessing the Welfare Costs of Household Investment Mistakes. Journal of Political Economy, 115, 707-747.

Collins, J. M. (2010). A Review of Financial Advice Models and the Take-up of Financial Advice. Center for Financial Security Working Paper No. 10-5.

Dhar, R., \& N. Zhu. (2006). Up Close and Personal: Investor Sophistication and the Disposition Effect. Management Science, 52, 726-740.

Frederick, S. (2005). Cognitive Reflection and Decision Making. Journal of Economic Perspectives, 19(4), 25-42. 
Gerhardt, R., \& A. Hackethal. (2009). The Influence of Financial Advisors on Household Portfolios: A Study on Private Investors Switching to Financial Advice. SSRN working paper 1343607.

Goetzmann, W. N., \& A. Kumar. (2008). Equity Portfolio Diversification. Review of Finance, $12,433-463$.

Guiso, J., \& T. Jappelli. (2006). Information Acquisition and Portfolio Performance. CEPR Discussion Paper no. 5901.

Hackethal, A., M. Haliassos, \& T. Jappelli. (2012). Financial Advisors: A Case of Babysitters. Journal of Banking and Finance, 36, 509-524.

Huberman, G. (2001). Familiarity Breeds Investment. Review of Financial Studies, 14, 659680.

Hung, A., \& J. Yoong. (2010). Asking for Help: Survey and Experimental Evidence on Financial Advice and Behavior Change. RAND Working Paper Series WR-714-1.

Kahneman, D., P. Slovic, \& A. Tversky. (1974). Judgment under uncertainty. Science, 185(4157), 1124-1131.

Kahneman, D., \& A. Tversky. (1979). Prospect Theory: An Analysis of Decision under Risk. Econometrica, 47(2), 263-291.

Kahneman, D., \& A. Tversky. (1982). The Psychology of Preference. Scientific American, 246(1), 160-173.

Kelly, M. (1995). All Their Eggs in One Basket: Portfolio Diversification of US Households. Journal of Economic Behavior and Organization, 27, 87-96.

Koestner, M., S. Meyer, \& A. Hackethal. (2012). Do Individual Investors Learn from their Mistakes?.

Kramer, M. (2012). Financial literacy, cognitive ability and financial advice-seeking. SSRN working paper 2081795.

Kruger, J., \& D. Dunning. (1999). Unskilled and Unaware of It: How Difficulties in Recognizing One's Own Incompetence Lead to Inflated Self-Assessments. Journal of Personality and Social Psychology, 77(6), 1121-1134.

Lusardi, A., \& O. S. Mitchell. (2006). Financial Literacy and Planning: Implications for Retirement Wellbeing. Working paper University of Darmouth.

Lusardi, A., O. S. Mitchell, \& V. Curto. (2012). Financial Sophistication in the Older Population. NBER working paper 17863.

Odean, T. (1998). Are investors reluctant to realize their losses? Journal of Finance, 53, 1775-1798. 
Polkovnichenko, V. (2005). Household portfolio diversification: A case for rank dependent preferences. Review of Financial Studies, 18, 1467-1502.

Shapira, Z., \& I. Venezia. (2001). Patterns of Behavior of Professionally Managed and Independent Investors. Journal of Banking and Finance, 25, 1573-1587.

Shefrin, H., \& M. Statman. (1985). The Disposition to Sell Winners too Early and Ride Losers too Long: Theory and Evidence. Journal of Finance, 40, 777-790.

Tversky, A., \& D. Kahneman. (1973). Availability: A heuristic for judging frequency and probability. Cognitive Psychology, 5(2), 207-232.

Van Rooij, M., A. Lusardi, \& R. Alessie. (2007). Financial Literacy and Stock Makret Participation. Journal of Financial Economics, 101(2), 449-472.

Vulkan, N. (2000). An economist's perspective on probability matching. Journal of Economic Surveys, 14, 101-118. 
Tables

Table 1: Descriptive Statistics

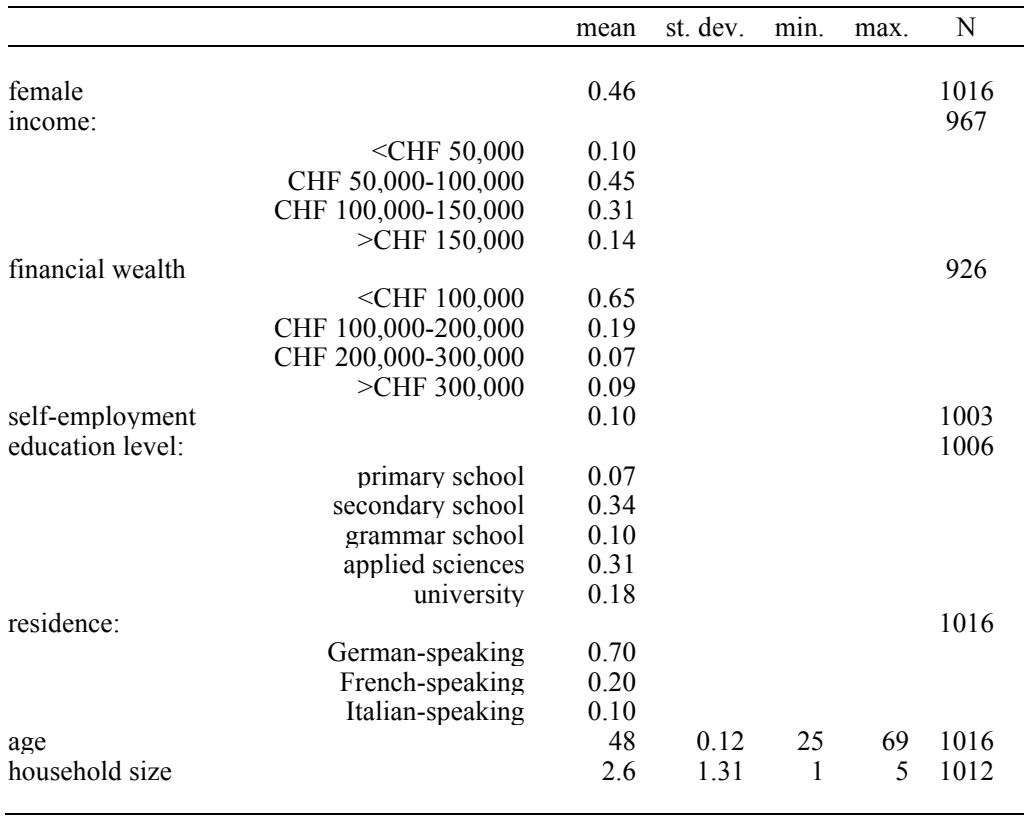


Table 2: Investment mistakes

\begin{tabular}{|c|c|c|c|c|c|c|c|c|c|c|c|c|}
\hline & a) & b) & c) & d) & e) & f) & g) & h) & NA & \multicolumn{3}{|c|}{$\begin{array}{l}\text { Participants with } \\
\text { investment mistakes }\end{array}$} \\
\hline past returns & $2 \%$ & $29 \%$ & $12 \%$ & $26 \%$ & $24 \%$ & $3 \%$ & $2 \%$ & $1 \%$ & $1 \%$ & & & $75 \%$ \\
\hline past risks & $3 \%$ & $2 \%$ & $3 \%$ & $5 \%$ & $42 \%$ & $7 \%$ & $33 \%$ & $3 \%$ & $2 \%$ & & & $56 \%$ \\
\hline performance drivers & $76 \%$ & $6 \%$ & $17 \%$ & & & & & & $1 \%$ & & & $23 \%$ \\
\hline risk diversification & $17 \%$ & $52 \%$ & $29 \%$ & & & & & & $2 \%$ & & & $69 \%$ \\
\hline time diversification & $10 \%$ & $59 \%$ & $29 \%$ & & & & & & $2 \%$ & & & $10 \%$ \\
\hline investing on a random walk & $40 \%$ & $57 \%$ & & & & & & & $3 \%$ & & & $57 \%$ \\
\hline reasons for continuing investing & $14 \%$ & $20 \%$ & $34 \%$ & $31 \%$ & & & & & $1 \%$ & & & $34 \%$ \\
\hline large unlikely payoffs & $70 \%$ & $8 \%$ & $20 \%$ & & & & & & $2 \%$ & & & $8 \%$ \\
\hline risk-taking after losses & $1 \%$ & $4 \%$ & $36 \%$ & $37 \%$ & $22 \%$ & & & & $1 \%$ & & & $5 \%$ \\
\hline behavior after losses & $11 \%$ & $3 \%$ & $39 \%$ & $46 \%$ & & & & & $1 \%$ & & & $53 \%$ \\
\hline behavior after gains & $58 \%$ & $9 \%$ & $31 \%$ & & & & & & $2 \%$ & & & $67 \%$ \\
\hline number of mistakes & 0 & 1 & 2 & 3 & 4 & 5 & 6 & 7 & 8 & 9 & 10 & 11 \\
\hline frequency & 4 & 17 & 47 & 136 & 219 & 221 & 178 & 78 & 18 & 8 & 0 & 0 \\
\hline cumulative prob. distribution & $0.4 \%$ & $2.3 \%$ & $7.3 \%$ & $22.0 \%$ & $45.7 \%$ & $69.5 \%$ & $88.7 \%$ & $97.2 \%$ & $99.1 \%$ & $100 \%$ & & \\
\hline
\end{tabular}

Note: The table shows the distribution of answers to the investment competence questions. The shaded numbers are the percentages of individuals whom we consider able to avoid mistakes. The lower part of the table shows the number of investment mistakes and its probability distribution. The questions and possible answers are included in the appendix. 
Table 3: Demand for financial advice

Which of the following statements best describes your willingness to delegate financial decisions to your present or a potential advisor whom you consider reliable?

I prefer to decide autonomously; the advisor should only execute my decisions

I prefer to tell my advisor how I would decide and would ask for his opinion

I prefer to get several opinions before I decide

I would trust my advisor in most decisions 
Table 4: Information sources

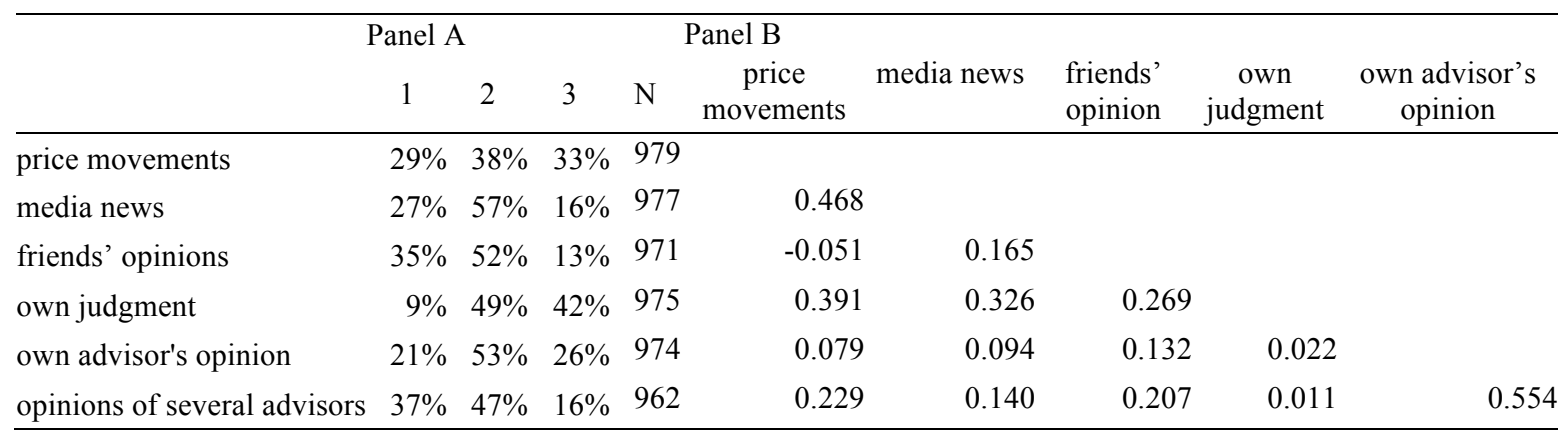

Note: The table reports summary statistics and polychoric correlations between statements on the perceived importance of information sources. The statements are ordinal variables taking values of 1 ("low importance"), 2 ("average importance"), and 3 ("high importance"). 
Table 5: Control variables

\begin{tabular}{|c|c|c|c|c|}
\hline & $\begin{array}{c}\text { decide } \\
\text { autonomously }\end{array}$ & $\begin{array}{c}\text { consult } \\
\text { an advisor }\end{array}$ & $\begin{array}{c}\text { consult } \\
\text { several advisors }\end{array}$ & $\begin{array}{l}\text { delegate } \\
\text { decisions }\end{array}$ \\
\hline investment competence & -2.27 & -2.22 & -2.10 & -2.07 \\
\hline price movements, media news, own judgment & 3.61 & 3.59 & 3.55 & 3.21 \\
\hline opinion of advisor(s) & 2.11 & 2.65 & 2.52 & 2.97 \\
\hline friends' recommendations & 2.15 & 2.18 & 2.40 & 2.09 \\
\hline investment experience index & 4.40 & 4.28 & 4.02 & 3.86 \\
\hline age & 45.9 & 48.4 & 47.1 & 48.7 \\
\hline female & $43 \%$ & $45 \%$ & $43 \%$ & $50 \%$ \\
\hline higher education & $48 \%$ & $49 \%$ & $52 \%$ & $50 \%$ \\
\hline self employment & $9 \%$ & $13 \%$ & $9 \%$ & $12 \%$ \\
\hline real estate ownership & $63 \%$ & $68 \%$ & $58 \%$ & $61 \%$ \\
\hline household size & 2.7 & 2.6 & 2.7 & 2.6 \\
\hline income (no statement) & $3 \%$ & $2 \%$ & $1 \%$ & $1 \%$ \\
\hline income $(<\mathrm{CHF} 50,000)$ & $10 \%$ & $8 \%$ & $8 \%$ & $8 \%$ \\
\hline income (CHF 50,000-100,000) & $40 \%$ & $47 \%$ & $40 \%$ & $47 \%$ \\
\hline income (CHF 100,000-150,000) & $31 \%$ & $26 \%$ & $31 \%$ & $33 \%$ \\
\hline income (>CHF 150,000) & $16 \%$ & $17 \%$ & $19 \%$ & $12 \%$ \\
\hline financial wealth (no statement) & $5 \%$ & $3 \%$ & $1 \%$ & $1 \%$ \\
\hline financial wealth $(<$ CHF 100,000$)$ & $63 \%$ & $55 \%$ & $62 \%$ & $57 \%$ \\
\hline financial wealth (CHF 100,000-200,000) & $16 \%$ & $19 \%$ & $18 \%$ & $18 \%$ \\
\hline financial wealth (CHF 200,000-300,000) & $5 \%$ & $7 \%$ & $8 \%$ & $5 \%$ \\
\hline financial wealth (>CHF 300,000$)$ & $11 \%$ & $16 \%$ & $11 \%$ & $19 \%$ \\
\hline German-speaking & $71 \%$ & $70 \%$ & $72 \%$ & $67 \%$ \\
\hline French-speaking & $16 \%$ & $18 \%$ & $21 \%$ & $24 \%$ \\
\hline Italian-speaking & $13 \%$ & $12 \%$ & $7 \%$ & $9 \%$ \\
\hline
\end{tabular}

Note: The table shows the distribution of characteristics for each group of individuals with the same willingness to delegate decisions. The distributions of characteristics are summarized by their means. 
Table 6: Advice seeking drivers

\begin{tabular}{|c|c|c|c|c|}
\hline & $\begin{array}{c}\text { decide } \\
\text { autonomously }\end{array}$ & $\begin{array}{c}\text { consult } \\
\text { an advisor }\end{array}$ & $\begin{array}{c}\text { consult } \\
\text { several advisors }\end{array}$ & $\begin{array}{l}\text { delegate } \\
\text { decisions }\end{array}$ \\
\hline investment competence index & $\begin{array}{r}-0.0291 * * \\
(0.0123)\end{array}$ & $\begin{array}{r}-0.0173 * * \\
(0.00751)\end{array}$ & $\begin{array}{r}0.0263 * * \\
(0.0113)\end{array}$ & $\begin{array}{c}0.0201 * * \\
(0.00851)\end{array}$ \\
\hline price movements, media news, own judgment & $\begin{array}{r}0.0467 * * * \\
(0.0164)\end{array}$ & $\begin{array}{r}0.0139 \\
(0.0182)\end{array}$ & $\begin{array}{r}-0.00198 \\
(0.0199)\end{array}$ & $\begin{array}{r}-0.0587 * * * \\
(0.0126)\end{array}$ \\
\hline advisor(s) opinion & $\begin{array}{r}-0.148 * * * \\
(0.0171)\end{array}$ & $\begin{array}{r}0.0469 * * \\
(0.0190)\end{array}$ & $\begin{array}{c}0.00615 \\
(0.0195)\end{array}$ & $\begin{array}{r}0.0945^{* * *} \\
(0.0124)\end{array}$ \\
\hline friends' recommendations & $\begin{array}{r}-0.0305 \\
(0.0197)\end{array}$ & $\begin{array}{r}-0.0411^{*} \\
(0.0219)\end{array}$ & $\begin{array}{r}0.110^{* * *} \\
(0.0238)\end{array}$ & $\begin{array}{r}-0.0383 * * \\
(0.0152)\end{array}$ \\
\hline investment experience index & $\begin{array}{l}0.0192 * * \\
(0.00808)\end{array}$ & $\begin{array}{l}0.0114 * * \\
(0.00495)\end{array}$ & $\begin{array}{r}-0.0174 * * \\
(0.00743)\end{array}$ & $\begin{array}{r}-0.0133 * * \\
(0.00561)\end{array}$ \\
\hline age & $\begin{array}{r}-0.00282 * * * \\
(0.00105)\end{array}$ & $\begin{array}{r}-0.00168^{* * * *} \\
(0.000649)\end{array}$ & $\begin{array}{r}0.00255^{* * *} \\
(0.000966)\end{array}$ & $\begin{array}{r}0.00195^{* * *} \\
(0.000733)\end{array}$ \\
\hline female & $\begin{array}{r}0.00749 \\
(0.0225)\end{array}$ & $\begin{array}{r}0.00444 \\
(0.0133)\end{array}$ & $\begin{array}{r}-0.00678 \\
(0.0203)\end{array}$ & $\begin{array}{r}-0.00515 \\
(0.0154)\end{array}$ \\
\hline higher education & $\begin{array}{r}-0.00382 \\
(0.0230)\end{array}$ & $\begin{array}{r}-0.00227 \\
(0.0137)\end{array}$ & $\begin{array}{r}0.00346 \\
(0.0208)\end{array}$ & $\begin{array}{l}0.00263 \\
(0.0159)\end{array}$ \\
\hline self-employment & $\begin{array}{r}-0.0105 \\
(0.0318)\end{array}$ & $\begin{array}{r}-0.00649 \\
(0.0205)\end{array}$ & $\begin{array}{l}0.00946 \\
(0.0287)\end{array}$ & $\begin{array}{l}0.00748 \\
(0.0236)\end{array}$ \\
\hline real estate ownership & $\begin{array}{r}0.0308 \\
(0.0233)\end{array}$ & $\begin{array}{r}0.0190 \\
(0.0150)\end{array}$ & $\begin{array}{r}-0.0278 \\
(0.0211)\end{array}$ & $\begin{array}{r}-0.0220 \\
(0.0173)\end{array}$ \\
\hline household size & $\begin{array}{l}-0.00494 \\
(0.00862)\end{array}$ & $\begin{array}{r}-0.00294 \\
(0.00515)\end{array}$ & $\begin{array}{r}0.00448 \\
(0.00781)\end{array}$ & $\begin{array}{r}0.00341 \\
(0.00595)\end{array}$ \\
\hline income (no statement) & $\begin{array}{r}-0.0586 \\
(0.0869)\end{array}$ & $\begin{array}{r}-0.0458 \\
(0.0861)\end{array}$ & $\begin{array}{r}0.0509 \\
(0.0679)\end{array}$ & $\begin{array}{l}0.0535 \\
(0.105)\end{array}$ \\
\hline income $(<$ CHF 50,000) & $\begin{array}{r}0.0227 \\
(0.0526)\end{array}$ & $\begin{array}{r}0.0123 \\
(0.0257)\end{array}$ & $\begin{array}{r}-0.0205 \\
(0.0473)\end{array}$ & $\begin{array}{l}-0.0145 \\
(0.0310)\end{array}$ \\
\hline income (CHF 50,000-100,000) & $\begin{array}{l}0.00258 \\
(0.0332)\end{array}$ & $\begin{array}{r}0.00153 \\
(0.0197)\end{array}$ & $\begin{array}{r}-0.00233 \\
(0.0301)\end{array}$ & $\begin{array}{r}-0.00177 \\
(0.0228)\end{array}$ \\
\hline income (CHF 100,000-150,000) & $\begin{array}{r}-0.0232 \\
(0.0310)\end{array}$ & $\begin{array}{r}-0.0145 \\
(0.0202)\end{array}$ & $\begin{array}{r}0.0210 \\
(0.0279)\end{array}$ & $\begin{array}{r}0.0167 \\
(0.0233)\end{array}$ \\
\hline financial wealth (no statement) & $\begin{array}{r}0.331 * * \\
(0.164)\end{array}$ & $\begin{array}{r}0.00124 \\
(0.0617)\end{array}$ & $\begin{array}{r}-0.235^{* * * *} \\
(0.0840)\end{array}$ & $\begin{array}{r}-0.0972 * * * \\
(0.0228)\end{array}$ \\
\hline financial wealth $(<\mathrm{CHF} 100,000)$ & $\begin{array}{r}0.0769 * * \\
(0.0349)\end{array}$ & $\begin{array}{r}0.0485 * * \\
(0.0233)\end{array}$ & $\begin{array}{r}-0.0686^{* *} \\
(0.0306)\end{array}$ & $\begin{array}{r}-0.0569 * * \\
(0.0278)\end{array}$ \\
\hline financial wealth (CHF 100,000-200,000) & $\begin{array}{r}0.0694 \\
(0.0453)\end{array}$ & $\begin{array}{r}0.0326^{* *} \\
(0.0164)\end{array}$ & $\begin{array}{r}-0.0619 \\
(0.0394)\end{array}$ & $\begin{array}{r}-0.0402 * \\
(0.0222)\end{array}$ \\
\hline financial wealth (CHF 200,000-300,000) & $\begin{array}{r}0.0465 \\
(0.0560)\end{array}$ & $\begin{array}{r}0.0224 \\
(0.0214)\end{array}$ & $\begin{array}{r}-0.0416 \\
(0.0493)\end{array}$ & $\begin{array}{r}-0.0273 \\
(0.0281)\end{array}$ \\
\hline French-speaking & $\begin{array}{l}-0.0175 \\
(0.0258)\end{array}$ & $\begin{array}{l}-0.0110 \\
(0.0171)\end{array}$ & $\begin{array}{r}0.0159 \\
(0.0233)\end{array}$ & $\begin{array}{r}0.0127 \\
(0.0196)\end{array}$ \\
\hline Italian-speaking & $\begin{array}{c}0.0714^{*} \\
(0.0418)\end{array}$ & $\begin{array}{r}0.0314 * * \\
(0.0133)\end{array}$ & $\begin{array}{c}-0.0634 * \\
(0.0359)\end{array}$ & $\begin{array}{r}-0.0395 * * \\
(0.0188)\end{array}$ \\
\hline $\begin{array}{l}\mathrm{N} \\
\text { Pseudo } \mathrm{R}^{2}\end{array}$ & & & & $\begin{array}{r}811 \\
0.0946\end{array}$ \\
\hline
\end{tabular}

Note: The table reports estimated marginal effects of partially proportional odds estimates on the probabilities of choosing one of the four delegation options. The base categories for the indicator variables are: male, lower education, employed or job-seeking, no real estate ownership, household's income > CHF 150,000, financial wealth > CHF 300,000, Germanspeaking. Robust standard errors are given in parentheses. Significance levels are denoted by asterisks: $* * * p<0.01, * * p<0.05, * p<0.1$. 
Table 7: Two-stage least square estimation results

First-stage: logistic regression consulting advisor(s)/delegation

importance of advisor(s) opinion

odds ratio $2.567 * * *$

other regressors (not reported)

(0.298)

$\mathrm{N}$

880

Main equation: investment competence

consulting advisor(s)/delegation

0.270

(0.291)

$\mathrm{N}$

815

Anderson canon. corr. LR statistic (Chi-sq(1) p-value)

$74.3(0.000)$ 
Table 8: Robustness tests on index construction

\begin{tabular}{lrrrr}
\hline & $\begin{array}{r}\text { decide } \\
\text { autonomously }\end{array}$ & $\begin{array}{r}\text { consult } \\
\text { an advisor }\end{array}$ & $\begin{array}{r}\text { consult } \\
\text { several advisors }\end{array}$ & $\begin{array}{r}\text { delegate } \\
\text { decisions }\end{array}$ \\
\hline Investment competence index (basis) & $-0.0291^{* *}$ & $-0.0173^{* *}$ & $0.0263^{* *}$ & $(0.0113)$ \\
& $(0.0123)$ & $(0.00751)$ & $-0.0201^{* *}$ \\
Investment competence index 1 & $-0.0122^{*}$ & $-0.00726^{*}$ & $(0.00851)$ \\
Investment competence index 2 & $(0.00652)$ & $(0.00394)$ & $(0.00594)$ & $(0.00452)$ \\
& $-0.0152^{* *}$ & $-0.00906^{* *}$ & $0.0138^{* *}$ & $0.0105^{* *}$ \\
& $(0.00734)$ & $(0.00446)$ & $(0.00672)$ & $(0.00510)$ \\
\hline
\end{tabular}

Note: The table reports the marginal effect of alternative investment competence indices on the probability of choosing one of the options regarding delegation in generalized logit regressions. The repressors (not reported here) are the same as in Table 6. Robust standards errors are in parentheses. Significance levels are denoted by asterisks: ${ }^{* * *} p \leq 0.01,{ }^{* *} p \leq 0.05, * p \leq 0.1$. Index 1 is based on the number of investment mistakes (without weights). Index 2 is similar to Index 1 but it averages the mistakes in the last two questions to take into account for their high correlation. 
Table 9: Robustness test on a subsample of participants with some investment experience

\begin{tabular}{|c|c|c|c|c|}
\hline & $\begin{array}{r}\text { decide } \\
\text { autonomously } \\
\end{array}$ & $\begin{array}{r}\text { consult } \\
\text { an advisor }\end{array}$ & $\begin{array}{r}\text { consult } \\
\text { several advisors } \\
\end{array}$ & $\begin{array}{r}\text { delegate } \\
\text { decisions }\end{array}$ \\
\hline investment competence index & $\begin{array}{r}-0.0288^{* *} \\
(0.0132)\end{array}$ & $\begin{array}{c}-0.0185 * * \\
(0.00876)\end{array}$ & $\begin{array}{r}0.0281 * * \\
(0.0131)\end{array}$ & $\begin{array}{c}0.0193 * * \\
(0.00892)\end{array}$ \\
\hline price movements, media news, own judgment & $\begin{array}{r}0.0449 * * * \\
(0.0144)\end{array}$ & $\begin{array}{r}0.0289 * * * \\
(0.00980)\end{array}$ & $\begin{array}{r}-0.0437 * * * \\
(0.0144)\end{array}$ & $\begin{array}{r}-0.0300 * * * \\
(0.00980)\end{array}$ \\
\hline advisor(s) opinion & $\begin{array}{r}-0.154 * * * \\
(0.0186)\end{array}$ & $\begin{array}{r}0.0507 * * \\
(0.0212)\end{array}$ & $\begin{array}{r}0.00600 \\
(0.0220)\end{array}$ & $\begin{array}{r}0.0977 * * * \\
(0.0136)\end{array}$ \\
\hline friends' recommendations & $\begin{array}{r}-0.0134 \\
(0.0211)\end{array}$ & $\begin{array}{r}-0.0482 * * \\
(0.0240)\end{array}$ & $\begin{array}{r}0.104 * * * \\
(0.0266)\end{array}$ & $\begin{array}{r}-0.0428 * * \\
(0.0167)\end{array}$ \\
\hline investment experience index & $\begin{array}{r}0.0280 * * * \\
(0.00945)\end{array}$ & $\begin{array}{r}0.0180 * * * \\
(0.00640)\end{array}$ & $\begin{array}{r}-0.0273 * * * \\
(0.00940)\end{array}$ & $\begin{array}{r}-0.0187 * * * \\
(0.00643)\end{array}$ \\
\hline age & $\begin{array}{r}-0.00269^{* *} \\
(0.00117)\end{array}$ & $\begin{array}{c}-0.00173 * * \\
(0.000781)\end{array}$ & $\begin{array}{r}0.00262^{* *} * \\
(0.00116)\end{array}$ & $\begin{array}{c}0.00180^{* *} \\
(0.000795)\end{array}$ \\
\hline female & $\begin{array}{r}0.0319 \\
(0.0251)\end{array}$ & $\begin{array}{r}0.0199 \\
(0.0153)\end{array}$ & $\begin{array}{r}-0.0309 \\
(0.0244)\end{array}$ & $\begin{array}{r}-0.0208 \\
(0.0161)\end{array}$ \\
\hline higher education & $\begin{array}{r}0.00821 \\
(0.0254)\end{array}$ & $\begin{array}{l}0.00529 \\
(0.0164)\end{array}$ & $\begin{array}{r}-0.00800 \\
(0.0248)\end{array}$ & $\begin{array}{r}-0.00550 \\
(0.0171)\end{array}$ \\
\hline self employment & $\begin{array}{l}0.00987 \\
(0.0356)\end{array}$ & $\begin{array}{r}0.00610 \\
(0.0211)\end{array}$ & $\begin{array}{r}-0.00959 \\
(0.0344)\end{array}$ & $\begin{array}{r}-0.00638 \\
(0.0222)\end{array}$ \\
\hline real estate ownership & $\begin{array}{r}0.0383 \\
(0.0254)\end{array}$ & $\begin{array}{r}0.0264 \\
(0.0189)\end{array}$ & $\begin{array}{r}-0.0374 \\
(0.0248)\end{array}$ & $\begin{array}{r}-0.0274 \\
(0.0195)\end{array}$ \\
\hline household size & $\begin{array}{r}-0.0126 \\
(0.00966)\end{array}$ & $\begin{array}{r}-0.00813 \\
(0.00631)\end{array}$ & $\begin{array}{r}0.0123 \\
(0.00947)\end{array}$ & $\begin{array}{r}0.00845 \\
(0.00650)\end{array}$ \\
\hline income (no statement) & $\begin{array}{r}-0.0782 \\
(0.0921)\end{array}$ & $\begin{array}{r}-0.0739 \\
(0.120)\end{array}$ & $\begin{array}{r}0.0724 \\
(0.0693)\end{array}$ & $\begin{array}{r}0.0797 \\
(0.143)\end{array}$ \\
\hline income $(<$ CHF 50,000$)$ & $\begin{array}{r}-0.000324 \\
(0.0578)\end{array}$ & $\begin{array}{r}-0.000209 \\
(0.0373)\end{array}$ & $\begin{array}{r}0.000316 \\
(0.0563)\end{array}$ & $\begin{array}{r}0.000217 \\
(0.0388)\end{array}$ \\
\hline income (CHF 50,000-100,000) & $\begin{array}{r}-0.00210 \\
(0.0357)\end{array}$ & $\begin{array}{r}-0.00135 \\
(0.0230)\end{array}$ & $\begin{array}{r}0.00204 \\
(0.0348)\end{array}$ & $\begin{array}{l}0.00140 \\
(0.0239)\end{array}$ \\
\hline income (CHF 100,000-150,000) & $\begin{array}{r}-0.00220 \\
(0.0339)\end{array}$ & $\begin{array}{r}-0.00142 \\
(0.0220)\end{array}$ & $\begin{array}{c}0.00214 \\
(0.0330)\end{array}$ & $\begin{array}{r}0.00148 \\
(0.0228)\end{array}$ \\
\hline financial wealth (no statement) & $\begin{array}{c}0.369^{*} \\
(0.200)\end{array}$ & $\begin{array}{r}-0.0172 \\
(0.0903)\end{array}$ & $\begin{array}{r}-0.255^{* * *} * \\
(0.0913)\end{array}$ & $\begin{array}{r}-0.0961^{* * *} * \\
(0.0235)\end{array}$ \\
\hline financial wealth $(<\mathrm{CHF} 100,000)$ & $\begin{array}{r}0.0853 * * \\
(0.0370)\end{array}$ & $\begin{array}{r}0.0560 * * \\
(0.0249)\end{array}$ & $\begin{array}{r}-0.0820^{* *} \\
(0.0350)\end{array}$ & $\begin{array}{r}-0.0593 * * \\
(0.0270)\end{array}$ \\
\hline financial wealth (CHF 100,000-200,000) & $\begin{array}{r}0.0752 \\
(0.0471)\end{array}$ & $\begin{array}{r}0.0372 * * \\
(0.0176)\end{array}$ & $\begin{array}{r}-0.0708^{*} \\
(0.0426)\end{array}$ & $\begin{array}{r}-0.0415^{*} \\
(0.0218)\end{array}$ \\
\hline financial wealth (CHF 200,000-300,000) & $\begin{array}{r}0.0897 \\
(0.0631)\end{array}$ & $\begin{array}{r}0.0373 * * \\
(0.0152)\end{array}$ & $\begin{array}{r}-0.0825 \\
(0.0540)\end{array}$ & $\begin{array}{r}-0.0445^{*} \\
(0.0236)\end{array}$ \\
\hline French-speaking & $\begin{array}{r}0.0120 \\
(0.0326)\end{array}$ & $\begin{array}{r}0.00739 \\
(0.0192)\end{array}$ & $\begin{array}{l}-0.0116 \\
(0.0315)\end{array}$ & $\begin{array}{r}-0.00774 \\
(0.0203)\end{array}$ \\
\hline Italian-speaking & $\begin{array}{r}0.0437 \\
(0.0431)\end{array}$ & $\begin{array}{r}0.0232 \\
(0.0186)\end{array}$ & $\begin{array}{r}-0.0417 \\
(0.0402)\end{array}$ & $\begin{array}{r}-0.0252 \\
(0.0215)\end{array}$ \\
\hline $\begin{array}{l}\mathrm{N} \\
\text { Pseudo } \mathrm{R}^{2}\end{array}$ & & & & $\begin{array}{r}652 \\
0.0927\end{array}$ \\
\hline
\end{tabular}

Note: The table reports marginal effects on the probability of choosing one of the options regarding delegation in a generalized logit regression on a subsample excluding individuals indicating no investment experience in any asset class. Standard errors are in parentheses. Significance levels are denoted by asterisks: $* * * p<0.01, * * p<0.05,{ }^{*} p<0.1$. 


\section{Appendix}

\section{A Description of Variables}

\begin{tabular}{|c|c|}
\hline Variable & Description \\
\hline female & dummy variable: 1 : female \\
\hline higher education & dummy variable: 1 : school of applied sciences or university \\
\hline self-employment & dummy variable: 1 : status is self-employment \\
\hline age & ordinal variable: number of years \\
\hline bonds world & ordinal variable: experience with international bonds investments (1: no experience - 4: high) \\
\hline Swiss bonds & ordinal variable: experience with Swiss bonds investments (1: no experience - 4: high) \\
\hline equity world & ordinal variable: experience with international equity investments (1: no experience - 4 : high) \\
\hline Swiss equity & ordinal variable: experience with Swiss equity investments (1: no experience - 4: high) \\
\hline alternative investments & ordinal variable: experience with alternative investments (1: no experience - 4 : high) \\
\hline price movements & ordinal variable: perceived importance of price movements (1: not important - 3: very important) \\
\hline news in media & ordinal variable: perceived importance of media news (1: not important -3 : very important) \\
\hline friends' opinion & ordinal variable: perceived importance of friends' opinion (1: not important - 3 : very important) \\
\hline own judgment & ordinal variable: perceived importance of own judgment (1: not important - 3: very important) \\
\hline opinion own advisor & $\begin{array}{l}\text { ordinal variable: perceived importance of the own advisor's opinion (1: not important - 3: very } \\
\text { important) }\end{array}$ \\
\hline opinion many advisors & $\begin{array}{l}\text { ordinal variable: perceived importance of the opinion of many advisors (1: not important }-3 \text { : very } \\
\text { important) }\end{array}$ \\
\hline German-speaking & dummy variable: 1 : residence in a German-speaking region \\
\hline French-speaking & dummy variable: 1 : residence in a French-speaking region \\
\hline Italian-speaking & dummy variable: 1 : residence in an Italian-peaking region \\
\hline
\end{tabular}

\section{B Investment Competence Questions}

Unbiased answers are given in italics.

\begin{tabular}{|c|c|}
\hline ast returns & $\begin{array}{l}\text { onsidering a long-term time period (e.g., } 30 \text { years), which assets normally are characterized by the } \\
\text { ghest returns? a) cash b) gold c) bonds d) real estate financial investments e) stocks f) commodities g) } \\
\text { dge funds h) private equity }\end{array}$ \\
\hline past risks & $\begin{array}{l}\text { Normally, which assets are characterized by the highest risk in the short-term (e.g., 1-2 years)? } \\
\text { a) cash b) gold c) bonds d) real estate financial investments e) stocks f) commodities g) hedge funds h) } \\
\text { private equity }\end{array}$ \\
\hline $\begin{array}{l}\text { rformance } \\
\text { ivers }\end{array}$ & $\begin{array}{l}\text { vestment success depends on several factors. Which of the following factors contributes most? } \\
\text { long-term allocation of wealth over several asset classes b) over- and underweighting of asset classes in } \\
\text { short-term c) security selection within asset classes }\end{array}$ \\
\hline risk diversification & s b) 5-10 stocks c) more than 10 stocks \\
\hline $\begin{array}{l}\text { time } \\
\text { diversification }\end{array}$ & $\begin{array}{l}\text { If one assumes that the average return on the Swiss stock market is } 5 \% \text { per year, then the probability of a } \\
\text { loss after one year is } 40 \% \text {. What is the probability of a loss after } 5 \text { years? } \\
\text { a) } 40 \% \text { or more b) less than } 40 \% \text { c) I cannot make such an estimation }\end{array}$ \\
\hline $\begin{array}{l}\text { ivesting on a } \\
\text { andom walk }\end{array}$ & $\begin{array}{l}\text { Suppose that the market price of a stock moves randomly and in more than half of cases rises. Which } \\
\text { strategy would you prefer? } \\
\text { a) buy and hold the stock until I need the money b) buy and hold the stock until I achieve a certain gain, } \\
\text { then sell and buy the stock again at a lower price. }\end{array}$ \\
\hline $\begin{array}{l}\text { continuing } \\
\text { investing }\end{array}$ & $\begin{array}{l}\text { Suppose you bought a financial asset. Which of the following factors do you consider most important for } \\
\text { you in remaining invested, i.e., keeping the asset? } \\
\text { a) that I made a gain with the asset b) that the asset follows a positive trend at the moment c) that the } \\
\text { investment idea still holds true d) I cannot decide because I have no investment experience with financial } \\
\text { assets. }\end{array}$ \\
\hline $\begin{array}{l}\text { large unlikely } \\
\text { payoffs }\end{array}$ & $\begin{array}{l}\text { Suppose you want to invest a large portion of your wealth for } 1-2 \text { years. Which of the following } \\
\text { investments is more attractive to you? } \\
\text { a) asset } A \text {, which offers a chance to win 10'000 Swiss francs in } 50 \text { of } 100 \text { cases b) asset B, which offers a }\end{array}$ \\
\hline
\end{tabular}


risk taking after losses

behavior after losses

behavior after gains
How do you assess the correctness of the following rule: "After large losses, one should take more risk to compensate for the losses"

a) always true b) often true c) sometimes true d) never true e) I cannot decide

Suppose you bought a financial asset for 100 Swiss francs. The current market price of the asset is 80 Swiss francs. What would you do?

a) I would buy more because the asset costs less b) I would sell because I made a loss c) I would not sell because otherwise I would realize a loss d) I would reconsider the investment idea.

Suppose you bought a financial asset for 100 Swiss francs. The current market price of the asset is 150 Swiss francs. What would you do?

a) I would realize the gain, i.e., I would sell the asset b) I would buy more because I made a gain c) I would reconsider the investment idea.

\section{Additional Empirical Results}

Table C.1: Investment experience

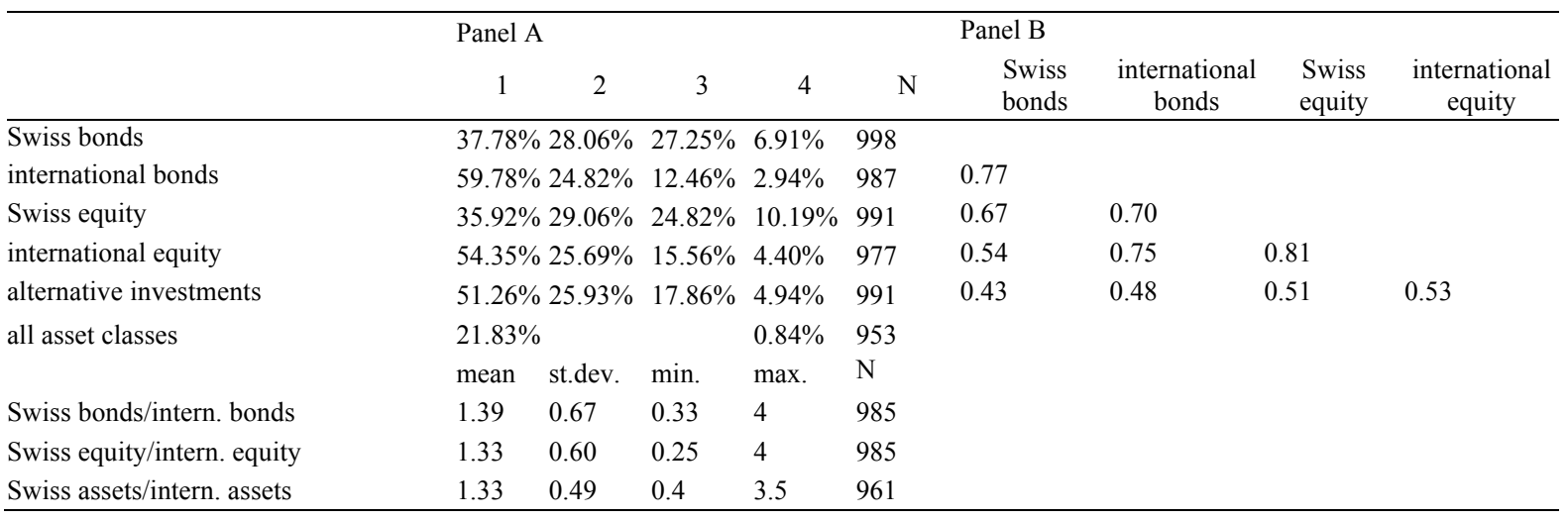

Note: Panel A reports the percentages of respondents evaluating their investment experience on a scale with four levels. 1 represents "no experience", 2 represents "limited experience", 3 represents "adequate experience", and 4 represents "extensive experience". The average experience is the sum of experience levels over all asset classes divided by the number of asset classes. The lower part of the panel reports summary statistics. Panel B reports polychoric correlations between experience statements across asset classes. ${ }^{1}$

\footnotetext{
${ }^{1}$ The polychoric correlations estimate what the correlation between households would be if ratings were made on a continuous scale. Theoretically, these correlations are invariant to changes in the number of rating categories.
} 
Table C.2: Construction of an investment experience index

\begin{tabular}{lllll}
\hline Panel A & & & \\
\hline Component & Eigenvalue & Difference & Proportion & Cumulative \\
Comp1 & 3.518 & 2.877 & 0.704 & 0.704 \\
Comp2 & 0.641 & 0.171 & 0.128 & 0.832 \\
\hline Panel B & & & & \\
\hline & Comp. 1 & Unexplained variance & & \\
Swiss bonds & 0.4385 & 0.3237 & \\
International bonds & 0.4788 & 0.1935 & \\
Swiss equity & 0.4771 & 0.1992 & \\
International equity & 0.4679 & 0.2299 & & \\
Alternative investments & 0.3633 & 0.5358 & &
\end{tabular}

Note: The table reports results of principal component analysis applied to the experience statements with different asset classes based on the matrix of polychoric correlations. The eigenvectors of the first principle are used to form an index of investment experience. 
Table C.3: Information sources weighting

\begin{tabular}{lllll}
\hline Panel A & & & & \\
\hline Component & Eigenvalue & Difference & Proportion & $\begin{array}{l}\text { Cumulative } \\
\text { Variance }\end{array}$ \\
Comp1 & 2.038 & 0.611 & 0.340 & 0.340 \\
Comp2 & 1.428 & 0.382 & 0.238 & 0.578 \\
Comp3 & 1.046 & 0.406 & 0.174 & 0.752 \\
Comp4 & 0.640 & 0.129 & 0.107 & 0.859 \\
& & & & \\
\hline Panel B & & & & \\
\hline & Comp1 & Comp2 & & Unexplained \\
price movements & 0.666 & & & 0.200 \\
media news & 0.571 & & & 0.395 \\
own judgment & 0.472 & & 0.878 & 0.332 \\
friends' recommendation & & & 0.101 \\
own advisor's opinion & & 0.692 & 0.247 \\
opinion of several advisors & & 0.691 & & 0.213 \\
\hline
\end{tabular}

Note: The table reports results of principal component analysis with varimax rotation applied to the stated importance of different information sources on the matrix of polychoric correlations. 
Table C.4: Advice seeking with an alternative measure of investment competence

\begin{tabular}{|c|c|c|c|c|}
\hline & $\begin{array}{r}\text { decide } \\
\text { autonomously } \\
\end{array}$ & $\begin{array}{r}\text { consult } \\
\text { an advisor } \\
\end{array}$ & $\begin{array}{r}\text { consult } \\
\text { several advisors } \\
\end{array}$ & $\begin{array}{r}\text { delegate } \\
\text { decisions } \\
\end{array}$ \\
\hline \multirow[t]{2}{*}{ investment competence index (alternative) } & $-0.0413 * *$ & $-0.0216 * *$ & $0.0384 * *$ & $0.0245 * *$ \\
\hline & $(0.0171)$ & $(0.00954)$ & $(0.0163)$ & $(0.0104)$ \\
\hline \multirow[t]{2}{*}{ price movements, media news, own judgment } & $0.0519 * * *$ & $0.0271 * *$ & $-0.0482 * * *$ & $-0.0308 * * *$ \\
\hline & $(0.0191)$ & $(0.0108)$ & $(0.0183)$ & $(0.0116)$ \\
\hline \multirow[t]{2}{*}{ advisor(s) opinion } & $-0.161 * * *$ & $0.0907 * * *$ & -0.0168 & $0.0872 * * *$ \\
\hline & $(0.0249)$ & $(0.0271)$ & $(0.0287)$ & $(0.0170)$ \\
\hline \multirow[t]{2}{*}{ friends' recommendations } & -0.0404 & -0.0307 & $0.0885 * * *$ & -0.0173 \\
\hline & $(0.0278)$ & $(0.0291)$ & $(0.0330)$ & $(0.0194)$ \\
\hline \multirow[t]{2}{*}{ investment experience index } & $0.0263 * *$ & $0.0138 * *$ & $-0.0245 * *$ & $-0.0156 * *$ \\
\hline & $(0.0107)$ & $(0.00599)$ & $(0.0102)$ & $(0.00649)$ \\
\hline \multirow[t]{2}{*}{ age } & $-0.00427 * * *$ & $-0.00223 * *$ & $0.00397 * * *$ & $0.00253 * * *$ \\
\hline & $(0.00157)$ & $(0.000889)$ & $(0.00150)$ & $(0.000959)$ \\
\hline \multirow[t]{2}{*}{ female } & 0.0506 & 0.0243 & -0.0466 & -0.0283 \\
\hline & $(0.0351)$ & $(0.0159)$ & $(0.0322)$ & $(0.0188)$ \\
\hline \multirow[t]{2}{*}{ higher education } & -0.00670 & -0.00350 & 0.00623 & 0.00397 \\
\hline & $(0.0341)$ & $(0.0177)$ & $(0.0317)$ & $(0.0202)$ \\
\hline \multirow[t]{2}{*}{ self employment } & -0.0392 & 0.0941 & $-0.120 *$ & 0.0648 \\
\hline & $(0.0563)$ & $(0.0737)$ & $(0.0650)$ & $(0.0508)$ \\
\hline \multirow[t]{2}{*}{ real estate ownership } & 0.0103 & 0.00547 & -0.00955 & -0.00619 \\
\hline & $(0.0340)$ & $(0.0185)$ & $(0.0317)$ & $(0.0208)$ \\
\hline \multirow[t]{2}{*}{ household size } & -0.000175 & $-0.0501 * * *$ & $0.0306^{*}$ & $0.0198 *$ \\
\hline & $(0.0149)$ & $(0.0155)$ & $(0.0181)$ & $(0.0109)$ \\
\hline \multirow[t]{2}{*}{ income (no statement) } & $-0.136 * *$ & -0.135 & $0.0949 * * *$ & 0.176 \\
\hline & $(0.0652)$ & $(0.104)$ & $(0.0241)$ & $(0.181)$ \\
\hline \multirow[t]{2}{*}{ income $(<$ CHF 50,000) } & 0.0747 & $-0.179 * *$ & 0.165 & -0.0605 \\
\hline & $(0.112)$ & $(0.0816)$ & $(0.128)$ & $(0.0578)$ \\
\hline \multirow[t]{2}{*}{ income (CHF 50,000-100,000) } & -0.0380 & -0.0208 & 0.0354 & 0.0235 \\
\hline & $(0.0443)$ & $(0.0254)$ & $(0.0411)$ & $(0.0286)$ \\
\hline \multirow[t]{2}{*}{ income (CHF 100,000-150,000) } & -0.0243 & -0.0132 & 0.0227 & 0.0149 \\
\hline & $(0.0398)$ & $(0.0226)$ & $(0.0371)$ & $(0.0253)$ \\
\hline \multirow[t]{2}{*}{ financial wealth (no statement) } & $0.398 *$ & -0.0390 & $-0.266 * * *$ & $-0.0931 * * *$ \\
\hline & $(0.204)$ & $(0.0958)$ & $(0.0916)$ & $(0.0231)$ \\
\hline \multirow[t]{2}{*}{ financial wealth $(<\mathrm{CHF} 100,000)$} & 0.0674 & 0.0350 & -0.0621 & -0.0402 \\
\hline & $(0.0464)$ & $(0.0243)$ & $(0.0425)$ & $(0.0282)$ \\
\hline \multirow[t]{2}{*}{ financial wealth (CHF 100,000-200,000) } & 0.0477 & 0.0212 & -0.0436 & -0.0253 \\
\hline & $(0.0535)$ & $(0.0201)$ & $(0.0480)$ & $(0.0255)$ \\
\hline \multirow[t]{2}{*}{ financial wealth (CHF 200,000-300,000) } & 0.0464 & 0.0196 & -0.0423 & -0.0238 \\
\hline & $(0.0678)$ & $(0.0225)$ & $(0.0601)$ & $(0.0300)$ \\
\hline \multirow[t]{2}{*}{ French-speaking } & -0.00634 & -0.00339 & 0.00590 & 0.00383 \\
\hline & $(0.0396)$ & $(0.0217)$ & $(0.0369)$ & $(0.0244)$ \\
\hline \multirow[t]{2}{*}{ Italian-speaking } & 0.0797 & $0.0282 *$ & -0.0709 & -0.0369 \\
\hline & $(0.0674)$ & $(0.0151)$ & $(0.0570)$ & $(0.0248)$ \\
\hline $\mathrm{N}$ & & & & 471 \\
\hline Pseudo $\mathrm{R}^{2}$ & & & & 0.1011 \\
\hline
\end{tabular}

Note: The table reports estimated marginal effects of partially proportional odds estimates on the probabilities of choosing one of the four delegation options. The investment competence index excludes "Don't know" answers. The base categories for the indicator variables are: male, lower education, employed or job-seeking, no real estate ownership, household's income $>$ CHF 150,000, financial wealth $>$ CHF 300,000, German-speaking. Robust standard errors are given in parentheses. Significance levels are denoted by asterisks: $* * * p<0.01, * * p<0.05, * p<0.1$. 
Table C.5: Advice seeking with interaction terms

\begin{tabular}{|c|c|c|c|c|}
\hline & $\begin{array}{r}\text { decide } \\
\text { autonomously }\end{array}$ & $\begin{array}{r}\text { consult } \\
\text { an advisor }\end{array}$ & $\begin{array}{r}\text { consult } \\
\text { several advisors } \\
\end{array}$ & $\begin{array}{r}\text { delegate } \\
\text { decisions }\end{array}$ \\
\hline \multirow[t]{2}{*}{ investment competence index } & $-0.0796^{* *}$ & $-0.0482 * *$ & $0.0731 * *$ & $0.0547 * *$ \\
\hline & $(0.0320)$ & $(0.0199)$ & $(0.0299)$ & $(0.0220)$ \\
\hline \multirow[t]{2}{*}{ investment competence* female } & 0.0372 & 0.0225 & -0.0342 & -0.0255 \\
\hline & $(0.0253)$ & $(0.0154)$ & $(0.0233)$ & $(0.0174)$ \\
\hline \multirow[t]{2}{*}{ investment competence*income(no statement) } & -0.00393 & -0.00238 & 0.00361 & 0.00270 \\
\hline & $(0.0913)$ & $(0.0552)$ & $(0.0838)$ & $(0.0627)$ \\
\hline \multirow[t]{2}{*}{ investment competence*income $\left(<\mathrm{CHF} 50^{\prime} 000\right)$} & 0.0248 & 0.0150 & -0.0227 & -0.0170 \\
\hline & $(0.0511)$ & $(0.0309)$ & $(0.0470)$ & $(0.0351)$ \\
\hline \multirow[t]{2}{*}{ investment competence*income (CHF 50’000-100’000) } & 0.0296 & 0.0179 & -0.0272 & -0.0204 \\
\hline & $(0.0345)$ & $(0.0210)$ & $(0.0318)$ & $(0.0237)$ \\
\hline \multirow[t]{2}{*}{ investment competence*income (CHF 100’000-150’000) } & 0.0464 & 0.0280 & -0.0426 & -0.0318 \\
\hline & $(0.0375)$ & $(0.0228)$ & $(0.0346)$ & $(0.0257)$ \\
\hline \multirow[t]{2}{*}{ investment competence*French-speaking } & $0.0511^{*}$ & $0.0309^{*}$ & $-0.0469 *$ & $-0.0351 *$ \\
\hline & $(0.0303)$ & $(0.0186)$ & $(0.0280)$ & $(0.0209)$ \\
\hline \multirow[t]{2}{*}{ investment competence*Italian-speaking } & -0.0423 & -0.0256 & 0.0388 & 0.0290 \\
\hline & $(0.0401)$ & $(0.0245)$ & $(0.0369)$ & $(0.0276)$ \\
\hline \multirow[t]{2}{*}{ price movements, media news, own judgment } & $0.0480 * * *$ & 0.0153 & -0.00352 & $-0.0597 * * *$ \\
\hline & $(0.0164)$ & $(0.0183)$ & $(0.0200)$ & $(0.0126)$ \\
\hline \multirow[t]{2}{*}{ opinion of advisor(s) } & $-0.146 * * *$ & $0.0474 * *$ & 0.00564 & $0.0931 * * *$ \\
\hline & $(0.0171)$ & $(0.0191)$ & $(0.0196)$ & $(0.0123)$ \\
\hline \multirow[t]{2}{*}{ friends' recommendations } & -0.0310 & $-0.0425^{*}$ & $0.111 * * *$ & $-0.0372 * *$ \\
\hline & $(0.0197)$ & $(0.0220)$ & $(0.0240)$ & $(0.0151)$ \\
\hline \multirow[t]{2}{*}{ investment experience index } & $0.0193 * *$ & $0.0117 * *$ & $-0.0177^{* *}$ & $-0.0133 * *$ \\
\hline & $(0.00812)$ & $(0.00503)$ & $(0.00756)$ & $(0.00560)$ \\
\hline \multirow[t]{2}{*}{ age } & $-0.0031 * * *$ & $-0.00188 * * *$ & $0.00285^{* * *}$ & $0.00213 * * *$ \\
\hline & $(0.00106)$ & $(0.000669)$ & $(0.000990)$ & $(0.000737)$ \\
\hline \multirow[t]{2}{*}{ female } & 0.0877 & 0.0496 & -0.0793 & -0.0581 \\
\hline & $(0.0622)$ & $(0.0326)$ & $(0.0548)$ & $(0.0399)$ \\
\hline \multirow[t]{2}{*}{ higher education } & -0.00586 & -0.00354 & 0.00538 & 0.00402 \\
\hline & $(0.0230)$ & $(0.0139)$ & $(0.0211)$ & $(0.0158)$ \\
\hline \multirow[t]{2}{*}{ self-employment } & -0.0142 & -0.00906 & 0.0130 & 0.0102 \\
\hline & $(0.0314)$ & $(0.0212)$ & $(0.0287)$ & $(0.0238)$ \\
\hline \multirow[t]{2}{*}{ real estate ownership } & 0.0308 & 0.0193 & -0.0282 & -0.0219 \\
\hline & $(0.0233)$ & $(0.0152)$ & $(0.0214)$ & $(0.0172)$ \\
\hline \multirow[t]{2}{*}{ household size } & -0.00612 & -0.00370 & 0.00562 & 0.00420 \\
\hline & $(0.00862)$ & $(0.00523)$ & $(0.00793)$ & $(0.00592)$ \\
\hline income (no statement) & -0.0747 & -0.0639 & 0.0636 & 0.0749 \\
\hline & $(0.157)$ & $(0.180)$ & $(0.106)$ & $(0.230)$ \\
\hline income $\left(<\mathrm{CHF} 50{ }^{\prime} 000\right)$ & 0.0691 & 0.0308 & -0.0620 & -0.0379 \\
\hline & $(0.143)$ & $(0.0435)$ & $(0.124)$ & $(0.0629)$ \\
\hline income (CHF 50’000-100’000) & 0.0579 & 0.0333 & -0.0528 & -0.0384 \\
\hline & $(0.0792)$ & $(0.0431)$ & $(0.0714)$ & $(0.0509)$ \\
\hline income (CHF 100’000-150’000) & 0.0741 & 0.0380 & -0.0670 & -0.0451 \\
\hline & $(0.0919)$ & $(0.0390)$ & $(0.0811)$ & $(0.0497)$ \\
\hline financial wealth (no statement) & $0.344 * *$ & -0.00279 & $-0.243 * * *$ & $-0.0977 * * *$ \\
\hline & $(0.166)$ & $(0.0652)$ & $(0.0830)$ & $(0.0221)$ \\
\hline financial wealth $\left(<\mathrm{CHF} 100^{\prime} 000\right)$ & $0.0707 * *$ & $0.0451 *$ & $-0.0641 * *$ & $-0.0517 *$ \\
\hline & $(0.0350)$ & $(0.0235)$ & $(0.0312)$ & $(0.0274)$ \\
\hline financial wealth (CHF 100'000-200'000) & 0.0671 & $0.0322 *$ & -0.0606 & $-0.0388^{*}$ \\
\hline & $(0.0451)$ & $(0.0169)$ & $(0.0397)$ & $(0.0221)$ \\
\hline financial wealth (CHF 200’000-300’000) & 0.0424 & 0.0212 & -0.0386 & -0.0251 \\
\hline & $(0.0555)$ & $(0.0224)$ & $(0.0496)$ & $(0.0283)$ \\
\hline French-speaking & 0.106 & $0.0449^{*}$ & -0.0937 & -0.0568 \\
\hline & $(0.0863)$ & $(0.0234)$ & $(0.0725)$ & $(0.0369)$ \\
\hline Italian-speaking & -0.0397 & -0.0280 & 0.0360 & 0.0317 \\
\hline & $(0.0898)$ & $(0.0731)$ & $(0.0795)$ & $(0.0834)$ \\
\hline $\mathrm{N}$ & & & & 811 \\
\hline
\end{tabular}

Note: The table reports estimated marginal effects of partially proportional odds estimates on the probabilities of choosing one of the four delegation options. The base categories for the indicator variables are: male, lower education, employed or job-seeking, no real estate ownership, household's income > CHF 150'000, financial wealth > CHF 300'000, Germanspeaking. Standard errors are given in parenthesis. Significance levels are denoted by asterisks: $* * * p<0.01, * * p<0.05, * p<0.1$. 
Table C.6: Investment competence drivers

\begin{tabular}{|c|c|c|c|}
\hline & $\begin{array}{r}\text { investment } \\
\text { competence index (basis) }\end{array}$ & $\begin{array}{r}\text { investment } \\
\text { competence index } 1\end{array}$ & $\begin{array}{r}\text { investment } \\
\text { competence index } 2\end{array}$ \\
\hline \multirow[t]{2}{*}{ price movements, media news, own judgment } & -0.0596 & $-0.114^{*}$ & -0.0678 \\
\hline & $(0.0370)$ & $(0.0675)$ & $(0.0601)$ \\
\hline \multirow[t]{2}{*}{ advisor(s) opinion } & 0.00591 & 0.0155 & 0.0264 \\
\hline & $(0.0378)$ & $(0.0699)$ & $(0.0620)$ \\
\hline \multirow[t]{2}{*}{ friends' recommendations } & 0.0192 & 0.0266 & -0.0157 \\
\hline & $(0.0458)$ & $(0.0851)$ & $(0.0766)$ \\
\hline \multirow[t]{2}{*}{ age } & 0.00224 & 0.00139 & -0.00147 \\
\hline & $(0.00299)$ & $(0.00565)$ & $(0.00500)$ \\
\hline \multirow[t]{2}{*}{ female } & $-0.150 * *$ & $-0.402 * * *$ & $-0.325 * * *$ \\
\hline & $(0.0650)$ & $(0.123)$ & $(0.109)$ \\
\hline \multirow[t]{2}{*}{ investment experience index } & -0.0244 & 0.00237 & -0.00513 \\
\hline & $(0.0235)$ & $(0.0454)$ & $(0.0398)$ \\
\hline \multirow[t]{2}{*}{ higher education } & 0.0192 & 0.00543 & $9.93 e-05$ \\
\hline & $(0.0676)$ & $(0.128)$ & $(0.113)$ \\
\hline \multirow[t]{2}{*}{ self-employment } & -0.0691 & -0.143 & -0.132 \\
\hline & $(0.0946)$ & $(0.180)$ & $(0.159)$ \\
\hline \multirow[t]{2}{*}{ real estate ownership } & $0.133^{*}$ & $0.228 *$ & 0.181 \\
\hline & $(0.0701)$ & $(0.128)$ & $(0.114)$ \\
\hline \multirow[t]{2}{*}{ household size } & -0.0134 & 0.0239 & 0.0213 \\
\hline & $(0.0267)$ & $(0.0495)$ & $(0.0439)$ \\
\hline \multirow[t]{2}{*}{ income (no statement) } & -0.284 & -0.444 & -0.476 \\
\hline & $(0.271)$ & $(0.612)$ & $(0.523)$ \\
\hline \multirow[t]{2}{*}{ income $(<\mathrm{CHF} 50,000)$} & $-0.259 *$ & $-0.510 *$ & -0.391 \\
\hline & $(0.146)$ & $(0.275)$ & $(0.238)$ \\
\hline \multirow[t]{2}{*}{ income (CHF 50,000-100,000) } & $-0.283 * * *$ & $-0.618 * * *$ & $-0.512 * * *$ \\
\hline & $(0.0972)$ & $(0.190)$ & $(0.168)$ \\
\hline \multirow[t]{2}{*}{ income (CHF 100,000-150,000) } & $-0.266 * * *$ & $-0.578 * * *$ & $-0.452 * * *$ \\
\hline & $(0.0962)$ & $(0.188)$ & $(0.165)$ \\
\hline \multirow[t]{2}{*}{ financial wealth (no statement) } & 0.204 & 0.109 & 0.238 \\
\hline & $(0.200)$ & $(0.432)$ & $(0.348)$ \\
\hline \multirow[t]{2}{*}{ financial wealth $(<\mathrm{CHF} 100,000)$} & 0.0316 & -0.123 & -0.110 \\
\hline & $(0.105)$ & $(0.198)$ & $(0.177)$ \\
\hline \multirow[t]{2}{*}{ financial wealth (CHF 100,000-200,000) } & -0.00102 & -0.206 & -0.174 \\
\hline & $(0.117)$ & $(0.223)$ & $(0.197)$ \\
\hline \multirow[t]{2}{*}{ financial wealth (CHF 200,000-300,000) } & -0.0756 & -0.352 & -0.234 \\
\hline & $(0.156)$ & $(0.294)$ & $(0.263)$ \\
\hline \multirow[t]{2}{*}{ French-speaking } & -0.0640 & -0.226 & -0.194 \\
\hline & $(0.0793)$ & $(0.154)$ & $(0.134)$ \\
\hline \multirow[t]{2}{*}{ Italian-speaking } & $-0.330 * * *$ & $-0.662 * * *$ & $-0.594 * * *$ \\
\hline & $(0.109)$ & $(0.191)$ & $(0.170)$ \\
\hline \multirow[t]{2}{*}{ Constant } & $-1.745 * * *$ & $-4.094 * * *$ & $-3.535 * * *$ \\
\hline & $(0.304)$ & $(0.566)$ & $(0.507)$ \\
\hline $\mathrm{N}$ & 815 & 815 & 815 \\
\hline R-squared & 0.048 & 0.068 & 0.060 \\
\hline
\end{tabular}

Note: The table reports the results OLS estimates. Robust standard errors are reported in parentheses. Significance levels are denoted by asterisks: $* * * p<0.01, * * p<0.05, * p<0.1$. Index 1 is the sum of investment mistakes (without weights).

Index 2 is similar to Index 1 but uses the average mistake in the last two questions to take into account their high correlation. 